\title{
The Effect of Cultural Integration on the Development of Listening Comprehension among Iranian Upper-Intermediate EFL Learners
}

\author{
Mohammad Ali Fatemi \\ Islamic Azad University, Torbat-e Heydarieh, Iran \\ Fatemeh Montazerinia \\ Islamic Azad University, Torbat-e Heydarieh, Iran \\ Sharifeh Shirazian \\ Islamic Azad University, Torbat-e Heydarieh, Iran \\ Maliheh Atarodi \\ Islamic Azad University, Torbat-e Heydarieh, Iran
}

Doi:10.7575/aiac.alls.v.5n.6p.55

Received: $10 / 08 / 2014$

URL: http://dx.doi.org/10.7575/aiac.alls.v.5n.6p.55

Accepted: 30/09/2014

\begin{abstract}
Cultural integration can be used as an effective learning practice in contexts of English as Foreign Language (EFL) classrooms. The present study aimed at investigating the effect of cultural integration on the development of Iranian EFL upper-intermediate learners' listening comprehension. To this end, fifty-two upper-intermediate EFL learners were selected based on the Quick Placement Test, developed by Oxford University Press and University of Cambridge Local Examinations Syndicate (2012). These participants were randomly assigned into experimental ( $\mathrm{N}=26)$ and control $(\mathrm{N}=26)$ groups. T-test analysis indicated significant effects of cultural integration on the development of listening comprehension on upper-intermediate EFL learners. The findings offer pedagogical implications for integrating First Language (L1) culture in EFL listening comprehension classrooms.
\end{abstract}

Keywords: L1 Culture, Cultural Integration, Listening Comprehension

\section{Introduction}

According to Brown (2001) listening is an important component in language learning and teaching. It first attracted special attention in the late 1970s with James Asher's work on Total Physical Response published in 1977. Thanajaro (2000) argues that listening is not only the first of the language art skills developed, it is also the skill which is most frequently used both in the classroom and in daily life.

Probably, EFL students learn English easier and more efficiently based on their prior cultural knowledge. Matching the material employed along with EFL learners' backgrounds can be resulted in a facilitated negotiation of meaning. EFL students can accumulate background knowledge regarding any issue through their native language culture. According to Nazary (2008), the students' native language plays a key role in teaching language skills and sub-skills as well as in performing classroom activities. In fact, L1 has several deliberate functions.

On the other hand, listening comprehension seems to be a challenging task in countries, e.g. Iran, where English is the foreign language. According to Martinez-Flor and Uso-Juan (n.d.) the primacy of listening has recently become clear and that it plays a considerable role in EFL learners' development of second language communicative ability.

Understanding audio-material in language classes requires the utilization of technological instruments such as computers, headphones, voice-recorders, etc. Moreover, EFL teachers need to eliminate their students' stress and anxiety in such environments so as to assist EFL students enhance their concentration. By meeting such circumstances and requirements, it is hoped that listening comprehension will be effective and fertile. It seems that the use of native culture in English classes can lessen EFL students' level of stress and anxiety. Cultural differences were found to be significant in creating anxiety (Hashemi \& Abbasi, 2013).

Koren (1997 as cited in Nazary 2008) investigated the impact of students' listening to lectures in a foreign language while taking notes in L1 on the development of their listening comprehension. She found the usage of translation while taking notes as a good strategy if the purpose was to comprehend and keep the material for future reading, as before a test.

Accordingly, the present study aims at exploring the impact of including L1 culture-based materials on the development of EFL learners' listening comprehension. Considering the communicative use of language, the significance of listening 
comprehension as an inseparable part of communicative competence becomes obvious. According to Kasmer (1999) many students experience some discord when learning a new language since they examine the differences between their native culture and the culture of the target language.

\subsection{Research question}

To obtain the objectives of the present study, the following research question was posed by the researcher:

Q1: Does culture integration have any significant effect on the development of listening comprehension among Iranian upper-intermediate EFL learners?

\subsection{Research null-hypothesis}

Therefore, the following research null-hypothesis was proposed:

Q2: Culture integration does not have any significant effect on the development of listening comprehension among Iranian upper-intermediate EFL learners.

\section{Review of Literature}

According to Alptekin (1993), expressing and understanding meanings in a given language includes two kinds of knowledge: systemic and schematic. Systemic knowledge is the forma/characteristics of language, including its syntactic and semantic dimensions. Schematic knowledge, on the other hand, is acquired in social contexts. It is an important part of the 'fit' existing between people's culture-specific cognition and their native language. Regarding native language learning, the child's schematic knowledge and systemic knowledge develop simultaneously. Given what is known about the promoting impacts of familiar schemas (or schemata) on foreign language acquisition, it is most natural for learners to depend upon their already established schematic knowledge when developing new systemic knowledge. Therefore, foreign language teaching materials utilizing target-language culture elements to present the systemic data are likely to interfere with this natural tendency. Alptekin (1993) argues that such teaching materials actually damage foreign language learning because of various reasons.

Jadallah and Hasan (n.d.) in an article regarding new trends in Using L1 (Arabic) in the EFL Classroom came to the conclusion that all the instructors who were native speakers of English and 62.5\% of non-native speakers of English preferred to employ Arabic in EFL teaching.

Seghers (2008) in an investigation regarding L1 culture in the EFL classroom and abroad concluded that whether or not learners bring their culture into the TESOL classroom appears to be dependent upon different factors; most notably the time spent interacting with English speakers in English both at home and abroad, and through other exposure to English speaking cultures, including TV programs. Age and gender also sound to strongly influence this - but again, if older male learners have experience interacting with other cultures, 4/age and gender impacts may disappear. As most English conversation students in Japan have not had an opportunity to experience regular interaction with English speakers on a daily basis including living abroad for an extended period of time, it is inevitable that these learners will bring their native culture into the classroom (Seghers 2008).

Benahnia (n.d.) in their study found that having information about culture appears essential in the area of foreign language teaching/learning. However, teachers should receive adequate instructions on how to deal with cultural issues and how to integrate the cultural elements in their teaching activities. It is also crucial to know which culture to concentrate upon (i.e. L1 culture, or L2 culture?) and how much of that culture should the learner be exposed to, and at which level?

Nazary (2008) explored Iranian university students' attitudes and perceptions toward the use of L1. According to his findings most students had a negative view and rejected L1 use in English classes. However, it was found that language proficiency played a role in this regard and students with different levels of language proficiency expressed different attitudes toward the L1 function in EFL settings. Undoubtedly, the constructive role of L1 in syllabus design, ELT methods, classroom management, instructing language learning skills and sub-skills, performing all kinds of activities and language evaluation of students, is frequently stressed.

Neff and Rucynski Jr (2013) in an article, entitled "Tasks for Integrating Language and Culture Teaching", gratified the authors of the present research as the survey results of the three tasks under study in that article confirmed what we suspected in developing our project - that the different context and focus of each task brings varying benefits to learners even though all three were communicatively oriented and involved both intercultural and language education. Through these three extended production tasks, we feel that EFL learners can better understand the nuances of culture that may not be immediately obvious in their daily lives or in the English-learning resources they typically rely on, such as video or textbook materials. The preparation involved also puts learners more in control of what they learn, and the performance element allows them to interact with the instructor and other students to a greater degree than they may ordinarily be used to.

Turkan and Çelik (n.d.) investigated the effects of integrating culture into EFL texts and classroom. They suggested lesson plans and came to the conclusion that intercultural competence should be promoted at every stage of the English language learning experience. To do so, English language learners got to assume the role of a comparative ethnographer and completely understood the role of their own identity while comparing their own culture and with the target culture. Embedded within this claim is that language awareness is not enough all by itself. Without doubt, cultural awareness should be integrated simultaneously with the development of language awareness. As a consequence, EFL teachers 
should try to assist their students to personalize a specific content by having them determine the differences between their own culture and the target culture. Discussion activities are suggested as an example of the same for teachers to employ in class. However, it is also cautioned that level-relevant discussion activities should be designed at as learners might lose interest in the content. It is stressed that the students' interest in the target culture should be cultivated and maintained at a level in which the students can remain actively engaged in the material, merely because intercultural competence will make them more aware of their own culture, as well as the target culture(Turkan, \&Çelik, n.d.) .

Holliday (1994, as cited in Kasmer, 1999) investigated the relationship between consciousness-raising and cultural awareness. Holliday found that using BANA methodology (methodologies derived and used in English-speaking environments: Britain, Australasia, and North America.) in countries with dissimilar cultures led to a rough adjustment for learners and teachers. Certainly this style of teaching doesn't consider the learners' mindsets as influenced by their cultural backgrounds.

Rubin (2011) in an article entitled "A review of second language listening comprehension research" scrutinized previous studies which had explored the effects of a variety of strategies on listening comprehension. Rubin' review (2011) showed that topic familiarity (Schmidt-Rinehart, 1992), prior knowledge (Dunkel, 1991), and religious background (Markham, 1988 \& Latham, 1987) significantly influenced a subject's recall and listening comprehension.

In a study, Arévalo (2010) explored the effect of songs on the development of listening comprehension. It was found that practicing listening with songs can be considered as an effective strategy to enhance listening comprehension. Arévalo (2010) argued that creating authentic listening activities according to students' listening skills could be improved and such activities could become culturally meaningful and motivating for them.

Hayati (2009) in an article entitled "The Impact of Cultural Knowledge on Listening Comprehension of EFL Learners" explored the effect of cultural knowledge on improving Iranian EFL learners' listening comprehension. It was found that the participants had different performances on the post-test indicating that acquaintance with culturally-oriented language material improves the Iranian EFL learners' listening proficiency (Hayati, 2009).

\section{Methodology}

\subsection{Participants}

Fifty-two Iranian Upper-intermediate EFL learners studying English in Torbat-e Heydarieh, Iran took part in this study based on a placement test (Quick Placement Test, Version 2). Only females were selected due to some segregation rules in language institutes of Torbat-e Heydarieh. The age of the participants ranged from 24 to 35 . These participants were randomly divided into control $(\mathrm{N}=26)$ and experimental $(\mathrm{N}=26)$ groups.

\subsection{Instrumentations}

The following instruments were employed by the researcher:

\subsubsection{Quick Placement Test}

In order to evaluate and select upper-intermediate EFL learners, a test developed by Cambridge University, including 60 multiple-choice items was administered to 110 EFL learners of Torbat-e Heydarieh language institutes. Those learners whose scores were 31-40 out of 60 were selected as the participants of the present study.

\subsubsection{Listening Test}

In order to evaluate the participants' performance in listening comprehension, a pretest and posttest were administered. The tests were adopted from the Basic Tactics for Listening book so as to assess the participants' listening comprehension.

\subsection{Procedure}

At the beginning of the study, a Quick-Placement Test (QPT) was administered to 110 EFL learners studying at institutes in Torbat-e Heydarieh. Those students whose scores were 31-40 out of 60 were selected as the subject of the study $(\mathrm{N}=52)$. These students were, then, assigned to control $(\mathrm{N}=26)$ and experimental $(\mathrm{N}=26)$ groups. One teacher taught both groups during the course of 12 sessions.

Participants in the control group received audio-materials based on an English culture (e.g. Christianity, English Festivals from the Basic Tactics book). In addition to the Basic Tactics' audio materials, participants in the experimental group also received audio materials related to their native culture, Farsi (e.g. Islamic issues, Iranian festivals, etc.). The time allocated for the practice of Farsi culture was 5 minutes per session. The course lasted for 15 sessions. At the end of the course participants of both groups sat for the posttest.

\section{Data Analysis}

Data obtained from the instruments were statistically analyzed to test the null-hypothesis. Results of pre-test are shown in Table 1. 
Table 1. Results of independent samples t-test for pretest

\begin{tabular}{lllllll}
\hline Group & $\mathrm{N}$ & $\mathrm{M}$ & $\mathrm{SD}$ & $\mathrm{df}$ & $\mathrm{t}$ & $\mathrm{p}$ \\
\hline Cont. & 26 & 15.65 & 1.12 & 50 & .21 & .83 \\
\hline Exp. & 26 & 15.58 & 1.41 & & & \\
\hline
\end{tabular}

As Table 1 shows, there is no statistically significant difference $(\mathrm{t}=.21 ; \mathrm{p}=.83>.05)$ between the mean of the control $(M=15.65)$ and the experimental $(M=15.58)$ groups in the pretest. Therefore, the homogeneity of the participants was confirmed at the outset of the study. Results of posttest are shown in Table 2.

Table 2. Results of independent samples t-test for posttest

\begin{tabular}{lllllll}
\hline Group & $\mathrm{N}$ & $\mathrm{M}$ & $\mathrm{SD}$ & $\mathrm{df}$ & $\mathrm{t}$ & $\mathrm{p}$ \\
\hline Cont. & 26 & 16.35 & 1.29 & 50 & 2.89 & .006 \\
\hline Exp. & 26 & 17.46 & 1.47 & & & \\
\hline
\end{tabular}

As Table 2 shows, participants in the experimental group $(\mathrm{M}=17.46, \mathrm{SD}=1.47)$ significantly outperformed the ones in the control group $(\mathrm{M}=16.35 ; \mathrm{SD}=1.29)$, because $\mathrm{p}$-value (.006) stands at less than .05. Consequently, the nullhypothesis which indicated that "Culture integration does not have any significant effect on the development of listening comprehension among Iranian upper-intermediate EFL learners" was rejected.

\section{Discussion And Conclusion}

The present study aimed at exploring the effect of culture integration on the development of listening comprehension among Iranian upper-intermediate EFL learners. One null-hypothesis was proposed by the researchers. As the findings demonstrate, cultural integration can help Iranian upper-intermediate EFL learners develop their listening comprehension. Analysis of data showed that participants in the experimental group significantly outperformed those in the control one. Thus, language teachers should provide their students with authentic materials. The finding lent support to Rubin's review (2011) which found that topic familiarity (Schmidt-Rinehart, 1992), prior knowledge (Dunkel, 1991) and religious background (Markham \& Latham, 1987) had a significant effect on a subjects' recall and listening comprehension. Similarly, Hayati (2009) found that acquaintance with culturally-oriented language material improves the Iranian EFL learners' listening proficiency (Hayati, 2009).

Cultural integration was shown, in the present study, as a factor which increased participants' interest in and motivation to listening comprehension. Selected topics practiced in experimental class caused the students to further engage in the class activities and discussions. Also, these participants' concentration, as a crucial factor of listening comprehension, was improved as a result of integrating materials based on Persian culture. Further, participants in the experimental group showed an increased level of interest in listening to audio materials which were based on their native culture. Thus, EFL teachers can integrate L1 culture in language classes as a whole and in listening tasks in specific. EFL curriculum designers can include L1 culture in language text books. Inclusion of such materials can result in better outcomes in listening classes where topic familiarity and prior knowledge can facilitate listening comprehension. Further research is required to fill in the existing gaps in other dimensions of EFL such as writing, speaking, and reading. Also, it is recommended to include digital applications in addition to the present independent variable in future research.

\section{References}

Alptekin, C. (1993). Target-language culture in EFL materials: ELT Journal Volume 47(2), 136-143.

Arévalo, E.A.R. (2010). The use of songs as a tool to work on listening and culture in EFL classes. Cuadernos de Lingüística Hispánica (15). Retrieved 11 July, 2014 from: http://www.redalyc.org/pdf/3222/322227521008.pdf.

Benahnia, A. (n.d.). The Role of Cultural Components in Shaping the L2 Learner's Identity and Intercultural Competence.

Brown, H.D. (2001). Teaching by principles: An interactive approach to language pedagogy. (2 ${ }^{\text {nd }}$ ed.) San Francisco State University Press

Hashemi, M. \& Abbasi, M; (2013) The Role of the teacher in Alleviating Anxiety in Language Classes - International Research Journal of Applied and Basic Sciences, 4 (3), 640-646.

Hayati, A.M. (2009). The Impact of Cultural Knowledge on Listening Comprehension of EFL Learners. English Language Teaching, 2(3), 144-152.

Jadallah, M.,\&Hasan, F. (n.d.). A review of some new trends in using L1 in the EFL Classroom. Retrieved 10 July, 2014 from: http://www.qou.edu/english/conferences/firstNationalConference/pdfFiles/drMufeed.pdf. 
Neff, P., \& Rucynski, J. (2013). Tasks for Integrating Language and Culture Teaching. Retrieved 25 June, 2014 from: http://americanenglish.state.gov/files/ae/resource_files/51_2_4_neff_rucynski.pdf

Kasmer, W. (1999). The role of translation in the EFL / ESL classroom. Retrieved July 16, 2014 from: http://www.birmingham.ac.uk/documents/college-artslaw/cels/essays/secondlanguage/kasmer2.pdf.

Martinez-Flor, AL., \& Uso-Juan, E. (n.d.) Toward acquiring communicative competence through listening. [Online]

Nazary, M. (2008): The Role of L1 in L2 Acquisition: attitudes of Iranian university students. Novitas-ROYAL, 2 (2), 138-153.

Rubin, J. (2011). A review of second language listening comprehension research [Online], Retrieved from: http://jan.ucc.nau.edu/ jgc/512/listening_rubin.pdf.

Seghers, S. (2008). L1 Culture in the EFL classroom and abroad: The International Journal of Language Society and Culture. Available at: www.educ.utas.edu.au/users/tle/JOURNAL/.

Thanajaro, M. (2000): Using Authentic Materials to Develop Listening Comprehension in English as a $2^{\text {nd }}$ Language Classroom [Doctor of Education Dissertation] Retrieved from: http://tewilson.wikispaces.com

Turkan, S. \& Çelik, S. (n.d.). Integrating Culture Into EFL Texts And Classrooms: Suggested Lesson Plans. NovitasROYAL, 1(1), 18-33. 